\title{
СОВРЕМЕННАЯ ФИЛОСОФИЯ ЮРИДИЧЕСКОГО ОБРАЗОВАНИЯ: ВЫЗОВЫ ГЛОБАЛИЗАЦИИ
}

\begin{abstract}
Аннотация: Статья посвящена анализу оснований и тенденций модернизации профессионального юридического образования, определяемой векторами развития права в условиях глобализации. Автор обращается к фундаментальным вопросам современного юридического образования сквозь призму правовой глобалистики. $C$ этих позищий осуществляется переосмысление предназначения и смысла юридической профессии в современном обществе, что задает предельный горизонт политики в сфере реформирования содержательных и институциональных аспектов юридического образования. Большое место в авторском исследовании занимает освещение интеграционных прочессов в рамках европейского образовательного пространства в целом и европейского пространства юридического образования. В качестве основы данных проиессов рассматривается европейская правовая культура. Проводимый анализ самым непосредственным образом связан с исследованием возможных направлений развития системы юридического образования в России. Методологической основой проведенного автором анализа выступает понимание философии современного юридического образования в качестве наиболее общих подходов и приниипов, которые фиксируют предназначение юридической профессии как на национальном, так и международном уровне. Автор исходит из тезиса о том, что повышение роли права в условиях глобализации предполагает формирование нового формата профессионального юридического образования, содействующего утверждению ценности права. Новизна проведенного исследования заключается в рассмотрении традиционных, а также новых проблем, встающих перед юридическим образованием, в контексте, с одной стороны, сближения правовых систем в условиях глобализации, а с другой- формирования общих образовательных пространств. Автор приходит к выводу о том, что юридическое образование в современном мире переходит к интереснейшую стадию осмысления задачи сочетания транснационализации и дальнейтего развития национальных традиций. Помимо этого акиентируется внимание на повышении актуальности личностного измерения профессионального юридического образования и новых конфигураций связей образования и науки.
\end{abstract}

Ключевые слова: Юридчческая профессия, ценности права, правовая глобалистика, Болонский процесс, юридическая наука, утилитаризм, фундаментальное образование, образовательное пространство, европейские ценности, конкурентоспособность образования.

Abstract: This article is dedicated to the analysis of the foundations and tendencies of modernization of the professional legal education that is defined by the vectors of development of law under the conditions of globalization. The author refers to the fundamental issues of the modern legal education through the prism of legal globalistics. These positions are the basis for rethinking the purpose and the point of legal profession in the modern society, which defines the limits of politics in the area of reform of the content and institutional aspects of legal education. A substantial part of this research includes the illumination of the integrational processes within the European education system as a whole, and the European field of legal education. The conducted analysis is directly linked to the research of the possible paths of development of the legal education system in Russia. The methodological foundation of the analysis consists in the understanding of the philosophy of modern legal education as more general approaches and principles that establish the purpose for the legal profession on both, national and international levels. The author bases the conclusion on the notion that increasing the role of law under the conditions of globalization suggests the forming of a new format of professional legal education that would solidify the value of law.

Keywords: Legal profession, values of law, legal globalistics, Bologna process, juridical science, utilitarianism, fundamental education, educational sphere, European values, competitiveness of education. 
DOI: $10.7256 / 1811-9018.2015 .3 .13279$

При цитировании этой статьи сноска на доі обязательна

\section{Право и политика $3(183) \cdot 2015$}

T о общему признанию, современное общество вступило в чрезвычайно неясную зону, в которой происходит деформация различных социальных институтов и социальной нормативности на национальном и международном уровне. В основании данных процессов - всеобъемлющий кризис легитимности социального порядка. Проявления данного кризиса различны, но они тесно связаны друг с другом и проистекают из эрозии определенных форм легитимности - правовой, моральной, политической, религиозной. Кризис в рамках отмеченных форм легитимности создает множество затруднений, имеющих такие последствия, как рост конфликтов и насилия, социальную неопределенность и напряжение, а также фрустрацию и депривацию. Как результат - снижение эффективного функционирования политических, социальных и правовых институтов.

В этой ситуации, повышается актуальность исследования содержательного наполнения феномена легитимности, идея которой, безусловно, не может не трансформироваться в условиях глобализационных сдвигов и сдвигов постсовременности. В частности, к одному из трендов осмысления феномена легитимности может быть отнесен охват данным термином новых предметных областей, включая мораль, религию, искусство. В сущности, понятие легитимности возвращается к своему изначальному содержательному объему. Это означает, что исследование данного феномена выходит из-под традиционного покрова теоретического политического дискурса и поэтому также вполне может быть применимо к праву.

Как возможно понимание права сквозь призму понятия легитимности? Является ли рациональным обсуждение применимости понятия легитимность к праву? Что может дать видение права в ракурсе оценки его легитимности для понимания его сущности? Таков далеко не полный перечень проблем, требующих своего разрешения.

1.Философия права перед лицом дисфункции легитимности социального порядка в условиях глобализации: новые предметные горизонты. О существовании проблематики легитимности права может свидетельствовать не только широкое распространение в последнее время термина «легитимность права», но и формирование целого ряда теоретических подходов, например, ценностного и процедурного ${ }^{1}$. Термин легитим-

${ }^{1}$ Wheatly, $S$. The Democratic Legitimacy of International Law. Portland: Hart Publishing, 2010. P. 11 - 14; Murphy, K., Tyler, T.R., Curtis, A. Nurturing Regulatory Compliance: Is Procedural Justice Effective When People Question the Legitimacy of Law? // Regulation \& ность права в контексте фундаментальной проблемы подчинения праву и места последнего в жизни общества и человека, несомненно, стал широко распространенным и в блогосфере ${ }^{2}$. Однако, на наш взгляд, данные констатации еще не означают приобретения анализируемым понятием системного концептуального статуса. Поэтому концептуализация легитимности права как системного явления, безусловно, может быть отнесена к одному из перспективным направлений в современной философии права. Это требует четких представлений об эвристических возможностях, связанных с формированием ее новой предметной области.

Несмотря на тот факт, что легитимность является многоаспектной, она обладает ключевыми критериями, например, признанием и доверием к социально-значимым явлениям, их оправданности на основании соответствия моральным, эстетическим, религиозным максимам (требованиям, правилам, идеалам, нормам). Как думается, глобализация привносит с собой некоторую опасность фрагментации феномена легитимности вследствие фрагментации механизмов легитимации, связанных с разными плоскостями бытия легитимности. В эпоху глобализации кризис легитимности можно назвать глобальным, т.е. охватывающим не только разные сферы, но и разные уровни - национальный и международный.

Предельным следствием ослабления «собранности» легитимности является не столько ее вхождение в стадию постоянного кризиса, сколько жизнь «по ту сторону легитимности». Дело в том, что глобализация, вовлекающая в свои процессы разные общественные отношения, сопровождается резкими изменениями и отходом от привычных стереотипов и установок. Возникает множество новых, вполне нетрадиционных отношений, сквозь призму которых нечто уже ранее устоявшееся и стереотипное воспринимается как на национальном, так и международном уровне в качестве непривычного и .... нелегитимного. Например,

Governance, 2009. Vol. 3(1). P. 1 -26; Sadurski, W. Law's Legitimacy and 'Democracy-Plus' // Oxford Journal of Legal Studies, 2006. Vol. 26(2). P. 377 - 409; Brook, T. The Legitimacy of Law in Literature: the Case of Albion W. Tourgée // Elon Law Review, 2012. Vol. 5(1). P. 170 - 198; Joerges, Ch. On the Legitimacy of Europeanising Europes's Private Law. European University Institute, 2003; Dyzenhaus, D. Hobbes and the Legitimacy of Law // Law and Philosophy, 2001. Vol. 2(5). P. 461 - 498.

2 Johari, Z.K. The Legitimacy of Law (May 04, 2012). Available at: http://blog.limkitsiang.com/2012/05/04/the-legitimacy-of-law; Legitimacy of Laws Democrats vs Tyrants (September 29, 2012). Available at: http://kpulawandsociety.wordpress.com/2012/09/29/legitimacy-oflaws-democrats-vs-tyrants. 
Дж. Кохен указывает на проблематизацию суверенитета государства в эпоху глобализации ${ }^{3}$. Аналогичную мысль, но уже в отношении понимания и восприятия демократии высказывает К. Крауч. С его точки зрения, мобилизация на современной политической сцене новых идентичностей бросает вызов традиционным представления о том, что есть демократия, а что является ее отрицанием ${ }^{4}$. Более того, в условиях формирования транснациональных сообществ лояльность граждан начинает адресоваться не государству, а ТНК, международным организациям, наднациональной бюрократии, «сообществам идентичностей»

Вместе с тем, легитимность как наиболее общее воплощение правильности не может быть отброшена, поскольку она является условием социально организованной жизни, не говоря уже о выстраивании системы международных отношений. Аналогично можно утверждать о том, что в рамках легитимности социального порядка важны все формы легитимности и особенно правовая легитимность, придающая социальному порядку формальную структурированность, приемлемость и обоснованность. Вместе с тем, право как инструмент легитимации само должно быть легитимным. В этом случае следует говорить о феномене легитимности права, который со всей необходимостью является предметом самостоятельного анализа.

За понятием легитимность закрепилось устойчивое содержание, которое отличается политико-центрированным дизайном и зачастую отождествляется с понятием легальность. Вместе с тем надо учитывать, что не во всех случаях легальность, т.е. соответствие власти различным конститутивным нормам права, в том числе процедурным, тождественна ее легитимности. Поэтому в целях использования данного понятия как средства описания процессов, происходящих в социальном порядке общества, возникает потребность вернуть к жизни более широкое понимание легитимности, существующей как в юридическом, так и метаюридическом аспектах. В наиболее обобщенном виде под ней следует понимать системное отношение к наиболее существенным сторонам и процессам культурной и социальной жизни сквозь призму признания, доверия и одобрения.

Возникает вполне правомерный вопрос о той системе, на основании которой возникает ситуация при-

\footnotetext{
${ }^{3}$ Cohen, J.L. Globalization and Sovereignty. Rethinking Legality, Legitimacy, and Constitutionalism. Cambridge, 2012.

${ }^{4}$ Круч К. Пост-демократия. М.: Изд. Дом ГУ - ВШЭ, 2010. С. 145.

${ }_{5}^{5}$ Малахов В.С. Государство в условиях глобализации. М.: Издательство «КДУ», 2007. С. $187-189$.
}

знания, доверия и одобрения тех или иных социальных институтов, включая институты власти и господства. Как точно отмечает Ю.Е. Пермяков, говоря о феномене легитимности власти, - «если юридическое содержание легитимности вбирает в себя всю совокупность средств, с помощью которых власть приобретает признаки социального института (порядок деятельности, компетенция, структура, полномочия), то метаюридическое содержание легитимности выражает способность власти к исторической ответственности, т.е. соответствие каким-либо не поддающимся формализации критериям» ${ }^{6}$. В качестве данных критериев выступают системы ценностей, воплощающие различные метафизические картины мира и, соответственно, того, что есть человек и власть, каковы обязанности их по отношению друг к другу. В сущности, в аналогичном ключе мыслить и В.А. Шатило, подчеркивающий, что легитимация иногда не имеет отношения к закону и даже может противоречить ему. В итоге, легитимация как процедуpa, в результате которой посредством которой государственная власть приобретает состояние правильности, оправданности, целесообразности, законности и т.д. и отвечает потребностям и установкам личности и общества, не всегда является формальным процессом

Безусловно, следует согласиться с тем, что понятие легитимность несет в себе моральные, религиозные, т.е. неюридические и неправовые (точнее - метаюридические и метаправовые) смыслы. Поэтому констатация легитимности различных социальных институтов, а не только власти, есть результат консенсуальной констатации их обоснованности со стороны ценностей и ценностных идеалов. Разумеется, если происходит деформация ценностного содержания личной и общественной жизни, то использование понятия легитимности как онтологического и оценочного понятия становится излишним. Это относится, в том числе, и к понятию «легитимность права», отражающего как ситуацию признанности права в качестве разумной, справедливой, оправданной сферы социального бытия, так и выступающего ключом к пониманию легитимности политической власти. Вместе с тем, основания

\footnotetext{
${ }^{6}$ Пермяков Ю.Е. Метаморфозы легитимности // Мир человека: нормативное измерение -3 . Рациональность и легитимность. Сборник трудов международной научной конференции (Саратов, 13 - 15 июня 2013 г.). Под ред. проф. И.Д. Невважая. Саратов: Издательство «Кубик», 2013. С. 309.

${ }^{7}$ Шатило В.A. Вопросы легализации и легитимации государственной власти // Мир человека: нормативное измерение - 3 . Рациональность и легитимность. Сборник трудов международной научной конференции (Саратов, 13 - 15 июня 2013 г.). Под ред. проф. И.Д. Невважая. Саратов: Издательство «Кубик», 2013. С. 348.
} 
DOI: $10.7256 / 1811-9018.2015 .3 .13279$

При цитировании этой статьи сноска на доі обязательна

\section{Право и политика 3 (183) • 2015}

легитимности права представляют собой самостоятельную философско-правовую проблему.

В том случае, когда говорится о кризисе доверия, например, к тем или социальным институтам и нормам, в том числе к действиям органов государственной власти, то это означает кризис легитимности. Причем кризис легитимности следует понимать в буквальном смысле - не как исчезновение доверия и признания, а именно как постановку под сомнение самого существования данных институтов. Кризис легитимности нельзя однозначно определить как положительное или отрицательное явление. Это скорее пауза, которая содержит как продуктивные моменты, например, переход к новым моделям легитимности, так и негативные - затруднения в функционировании личности и общества в ситуации «нескладывающейся» легитимности.

Как думается, кризис легитимности связан, прежде всего, с повсеместным распространением духа свободы и с приверженностью идее свободы - экономической, культурной, политической, личностной. Свобода стала элементом современного образа жизни и любое ее ограничение рассматривается как посягательство на «святая святых». С точки зрения обострения чувства свободы многое видится и рассматривается как препятствующее утверждению воли к свободе, ныне не знающей границ и приводящей к усилению духа критицизма. Как точно отмечает Д. Дзоло, повышение дифференциации и колоссальное распространение мобильности, знаний и возможностей для нового опыта, происходящее благодаря технологическим новшествам, резко обостряет потребность в функциональной свободе и личной независимости. Однако именно жажда негативной свободы («свободы от»- М.Ш.) сопровождается отходом от политического консенсуализма и традиционных форм социальной организации. В результате образуется эрозия публичного измерения социальной жизни и личной независимости. Как итог, сверхсложная социальная система с трудом поддается управлению ${ }^{8}$

В этих условиях актуализируется вопрос о правомерности ограничений свободы, который позволяет нам оживить традиционный вопрос о соотношении права и свободы. Но как определить степень легитимности самой свободы? Как свобода может быть установлена в качестве основы легитимности? На фоне этой концептуальной коллизии право выступает в качестве глубинной и системной платформы легитимации социального порядка, оформляющей ее индикативный критерий, а именно свободу.

${ }^{8}$ Дзоло Д. Демократия и сложность: реалистический подход. М.: Изд. Дом ГУ - ВШЭ, 2010. С. $311-312$.

414
Представляется, что наиболее впечатляющие и чрезмерные проявления эрозии легитимности - это сомнения в обоснованности базовых идеологических и нормативных конструкциях общества, включая мировое сообщество. Названный кризис имеет прямое отношение к напряженности в правовом порядке общества и тем самым открывает пространство для критической работы философской рефлексии. Этот факт вновь подтверждает актуальность философской и философско-правовой рефлексии, нацеленной на утверждение релевантных моделей легитимации социального порядка, а также легитимации правового порядка общества. C нашей точки зрения, данное видение представляет собой конкретизацию применительно к философии права той политики философии, которая в настоящее время стоит перед новыми вызовами и характеризуется В. Подорогой как реализация призванности к тому, чтобы служить методологической основой для глобальной «переоценки всех ценностей» 9 .

Современная философия права находится под воздействием ситуации проблематичности легитимности и устремлена к тому, чтобы дать адекватный мировоззренческий ответ. Кроме того, философия права не ищет того, чтобы избегать множества проблем, так как последние являются проблемами предмета ее заинтересованности, нуждающихся в том, чтобы быть продуманными в пределах совершенно новых маршрутов философско-правовой рефлексии. Мы можем признать, что современная правовая философия несет ответственность за выработку концептуальных решений, создающих перспективы преодоления кризиса легитимности. Более того, философия права сама выступает значимым компонентом процесса легитимации, что предопределяет углублении ее рефлексии относительно феноменов легитимности и легитимации.

Легитимность является темой как политической, так и правовой философии. Однако прочно «оккупировала» данный феномен именно политическая философия, установившая специфическую линзу восприятия легитимности и легитимизации в качестве политической ситуации и политического процесса, основанного на праве и легальных процедурах. Необходимо признать, что данная философия, действительно, широко осветила содержание феномена легитимности, создав массивный блок научных изысканий (F. Barnard, D. Beetham, K. Binmore, A. Buchanan, J. Cohen, J. Hampton, S. Hershovitz, B. Manin, F. Peter, P. Riley, J. Waldron, Ch. Wellman).

${ }_{9}^{9}$ Подорога В. Апология политического. М.: Изд. Дом ГУ - ВШЭ, 2010. C. 18. 
В политической философии и политических науках легитимность понимается различным образом, но с сохранением базисных концептуальных смыслов. Она обычно представляется как принятие власти населением, признание ее авторитета и согласия с последней как с «правительственным режимом». В итоге, легитимность есть ситуация, когда граждане или подданные добровольно исполняют обязанность подчинения решениям власти ${ }^{10}$.

Принуждение в этом случае приобретает легитимную природу. Системное продумывание отмеченного ракурса легитимности создает впечатление, что легитимность как некое исследовательское поле является более близкой политической философии, нежели правовой философии. Тем не менее, философия права в силу своей дисциплинарной самостоятельности не может и не должна жить за счет политической философии, часто обращающейся к правовому дискурсу как широко принятому контексту своих размышлений. Конечно, различение между правовой и политической философией является условным и относительным. Поэтому феномен легитимности власти и в конечном счете легитимности социального порядка социального порядка находится на пересечении политической и правовой философии. Однако, феномен легитимности права - это преимущественное поле именно философско-правовых исследований.

В этом свете появляется необходимость разъяснить различие между подходами политической и правовой философии к легитимности. Политическая философия, разрабатывая концепции легитимности, хорошо осведомлена об импликациях философскоправового характера и включает отсылки к ним. В силу прозрачности предметных границ между политической и правовой философией, следует предположить существование интегрированной политико-правовой теории легитимности, представленной множеством концепций. При этом надо помнить, что понимание феномена легитимности, его исторических форм и источников находится также в сфере моральной философии. Это ведет к признанию необходимости координации усилий политической, моральной и правовой философии.

${ }^{10}$ Jackson, J., Bradford, B., Hough, M., Mihil, A., Quinton, P., Tyler, T. Why Do People Comply with the Law? Legitimacy and the Influence of Legal Institutions // British Journal of Criminology, 2012. Vol.52(6). P. 1051 - 1071; Tyler, T.R. Why People Obey the Law. Princenton: Princenton University Press, 2006; Wellman, Ch., Simmons, J. (eds.) Is There a Duty to Obey the Law? Cambridge: Cambridge University Press, 2005; Edmundson, W.A. (ed.) The Duty to Obey the Law: Selected Philosophical Readings, Oxford: Rowman\&Littlefield, 1999.
Ввиду того, что право связано с властью, философско-правовая концептуализация легитимности охватывает отношение между правом и властью. Власть посредством легальных процедур интегрируется в правовой порядок общества, становясь легитимной властью и далее подтверждая незыблемость общественного порядка. Как указывал М. Вебер, легальные процедуры позволяют нам ассоциировать и принимать власть в качестве политической власти, обладающей узаконенными основаниями принуждения. Законная власть есть развивающаяся опора права: она обеспечивает исполнение норм права, будучи, в идеале, подчинена праву.

Очень часто доверие к праву определяется доверием к действиям всех ветвей власти. Таким образом, правовая философия начинает с видения законной власти в качестве необходимого условия механизма реализации права. Среди ветвей власти судебная и законодательная власть являются более интересными для правовой философии, чем исполнительная власть, которая более интересна политической философии. Если законодательная и судебная власть помещаются в поток философско-правовых размышлений, то процедурный аспект их активности также становится предметом ее интереса, так как эти аспекты являются неотъемлемой частью легитимности права. В процессе концептуализации выше упомянутых аспектов, может быть привлечена концепция политической легитимности Д. Эстланда ${ }^{11}$. Данный автор видит ее как чисто процедурную легитимность В рамках своей концепции эпистемического процедурализма он рассматривает последнюю как чисто процедурную легитимность, вместе с тем не сводимую только к осуществлению независимых процедурных стандартов.

Действия властей, которые могут быть привлекательными для философско-правовой мысли, должны быть живой картиной всего правового, правильного, должного, справедливого и законного. Вследствие того, что право означает господство правового начала, власть существуют для претворения данного господства. Легитимность права, безусловно, основана на соответствующем функционировании законодательной и судебной власти, не говоря уже о функционировании исполнительной власти. Поэтому правовая философия может включить в круг своей концептуализации рефлексию о роли процедурных моментов существования власти не только для формирования легитимности власти, но и для утверждения легитимности права.

\footnotetext{
${ }^{11}$ Estlund, D. M. Democratic Authority: A Philosophical Framework. Princeton, 2008. P. 108.
} 
DOI: $10.7256 / 1811-9018.2015 .3 .13279$

При цитировании этой статьи сноска на doi обязательна

\section{Право и политика 3 (183) 2015}

Действительно, легитимация власти благодаря процедурам легальности представляет собой центральную предметную значимость для политической легитимности. Если политическая философия концентрируется на данной теме, принимая во внимание важность права как процедурного аспекта власти, то правовая философия наблюдает данную ситуацию в другом разрезе. Здесь подразумевается центральное значение легитимности права как признания и принятия его населением в качестве возможности правовой, истинной и справедливой реальности, а также как стража правового начала, а также истинного и справедливого социального порядка.

Обсуждение легитимности власти в аспекте предлагаемого акцентироания легитимности права имеет важные последствия. Дело в том, что глобализация сопровождается также такой тенденцией как расширение воли к власти. Возникновение открытых пространств порождает особые конфигурации властеотношений. Происходящее усложение понимания феномена власти связано с ценностной дезинтеграцией общества. Как правильно отмечает С. Льюкс, «само определение власти, а также любое использование такого определения, коль скоро оно имеется, неразрывно связано с существующей (возможно, непризнанной) системой ценностных представлений, которые предопределяют сферу ее эмпирического применения» ${ }^{12}$. Как следствие, проблема легитимности власти в условиях глобализации проявляется в новом ракурсе, что также образует новый уровень осмысления соотношения власти, с одной стороны, и права - с другой, как являющегося эталоном признания или непризнания власти в качестве легитимной. В круг кризиса легитимности объективно попадает и власть, «расползающаяся» в условиях глобализации и приобретающая новые, более усложненные формы. Иными словами, право актуализируется в качестве основы признания свободы и власти, являющихся своего рода противоположными явлениями человеческой жизни. Более того, оно видится в качестве мерила признания разных сторон социального порядка в качестве легитимных и нелегитимных.

Все сказанное означает, что в философию права входит понимание легитимности как центрального элемента функционирования социального порядка. Здесь философия права пересекается с социальной философией, демонстрируя свою фундаментальность. Но также вполне очевидно и то, что философия права

12 Льюкс С. Власть: Радикальный взгляд. М.: Изд. Дом ГУ - ВШЭ, 2010. C.48. должна интересоваться именно легитимностью и легитимацией права как измерения легитимности социального порядка, рассматривая право в качестве одной из опор легитимности последнего. Оформляющее воздействие права может быть уточнено как власть права. Одновременно возникает вопрос - к какому разделу философии права относится система теоретических представлений о легитимности права? Мы полагаем, что данное понятие вполне вписывается в круг категорий отнологии права, к которым, напрмиер, Г.А. Гаджиев относит понятия правовой релаьности, онтологической струтуры, правовой действительности ${ }^{13}$. Но вряд ли можно сомневаться в том, что данное понятие относится уже в качестве оценочного понятия к такому разделу философии права, как правовая аксиология.

В соответствии с таким пониманием философия права должна стремиться вписывать право, понятое как правовая реальность и правовой порядок, в широкий социально-культурный контекст. В соответствии с таким видением легитимность права не априорна, а является результатом процедур легитимации. Следовательно, философия права, обосновывая идею права, работает над его сущңностной легитимацией, показывая его значимость и необходимость для общества и личности. Одновременно такая работа философии являтся исторической, поскольку каждая эпоха предполагает свои требования к праву, отвечая которым, оно становится легитимным. Поэтому нет ничего страшного в деструкции исторически отживших пластов идеи права, а также в критике существующих форм правового бытия. Однако все это должно быть вспомогательным моментом конструктивной работы по обновлению идеи права и его легитимности.

2. От легитимности социального порядка к легитимности права: новые горизонты философскоправовой рефлексии. О всеобщей легитимности права представляется возможным говорить как о достоинстве его принципов, правил и институтов. Это также могло бы быть сказано о легитимности как достоинстве политических институтов, политических действий и решений. С этой точки зрения, право есть исходная реальность, а власть есть производная реальность, существующая в качестве важного инструмента, который должен быть легализирован, т.е. интегрирован в право. В результате власть, с точки зрения идеи господства права, есть «проводник» прав через создание законо-

\footnotetext{
${ }^{13}$ Гаджиев Г. А. Онтология права: (критическое исследование юридического концепта действительности). М.: Норма, 2014. С.11.
} 
дательства как позитивной формы права, не редуцируемой, как известно, к праву в целом.

Описанные детали имеют принципиальное значение для современной теории легитимности, развиваемой правовой философией, объясняющей специфику понимания легальности и легитимности на политическом и правовом уровне. Расхождения в понимании подтверждает одну регулярность, связанную с тем, что в политическом аспекте действия правительства могут быть легальными, не будучи легитимными и наоборот. Возможна ситуативная оппозиция того факта, когда правительственные действия являются легитимными, не будучи легальными. Легальность представляет собой корреляцию с правовыми правилам и правовыми процедурами; легитимность же, в соответствии с ее правовым смыслом, представляет собой корреляцию принципам и ценностям права, но не только. Поскольку мораль является более глубоким обоснованием легитимности социального порядка, то только что отмеченный случай легитимности без легальности преимущественно обладает моральной природой. Право, основываясь на морали, призвано разрешить коллизию между легитимностью и легальностью посредством выработки соответствующих правовых процедур.

Обсуждаемые особенности феномена легитимности могут соотнесены с концепцией легитимности А. Башанана, в которой защищается морализированная версия легитимности ${ }^{14}$. Он указывает, что действующая политическая власть обладает политической легитимностью, если только она морально оправдана. Таким образом, оправданная власть оказывается приемлемой для людей. Но, как подчеркивает А. Симмонс, это обстоятельство является необходимым, но недостаточным для политической легитимности ${ }^{15}$. Со своей стороны мы полагаем, что моральная оправданность власти нуждается в дополнении легальными процедурами, которые способны оформить обязательства граждан повиноваться распоряжениям правительства в соответствии с более универсальной основой общего и индивидуального согласия поступать именно таким образом.

Думается, что разрешение диссонанса между легальностью и легитимностью власти предполагает учет моральной нагруженности принципов права, находящихся в основе правовых правил и процедур. Как результат такого подхода, политическая власть должна быть легальной и легитимной, что представляет собой

${ }^{14}$ Buchanan, A. Political Legitimacy and Democracy // Ethics, 2002. Vol. 112(4). P. 689.

${ }^{15}$ Simmons, A. Justification and Legitimacy: Essays on Rights and Obligations. Cambridge, 2011. P. 137. существенное условие легитимности правовых правил, производных от власти. Власть представляет собой стража легитимности права и легитимности правового порядка в общем. Другим стражем выступают граждане. Их следование праву является центральным барьером для незаконных импульсов власти.

Возможности правовой философии по исследованию феномена легитимности связаны с потенциалом философской рефлексии в понимании изначального смысла легитимности как результата признания $и$ принятия чего-то и кого-то в качестве правого и истинного, что тесно связано с выделяемой У. Кимликой вслед за Дж. Ролзом некой интуицией правильного и неправильного ${ }^{16}$. Широкое определение легитимности позволяет с предельной абстракцией осуществить максимальное «схватывание» субстанции легитимности, которая вдохновляет работу философской мысли. Во всеобъемлющей философской перспективе легитимность является синонимом кластера таких оценочных понятий, как правое, истинное и справедливое. Система оценок охватывает моральную, политическую, экономическую и правовую сферы общества. Термины «легитимность», «легитимация», «легитимизация» не должны пониматься в качестве простых коннотаций. Поэтому хотелось бы предложить дефиницию легитимности как системного единства этих оценок. Как результат данного методологического подхода, легитимность в более конкретизированных формах предусматривает легальность и моральность.

Как следует определять легитимность права? Для правовой философии важно, во-первых, осветить легитимность как результат признания и принятия социального порядка, социального процесса и различных аспектов человеческой жизни, которые корреспондировали бы правовым установлениям. Корреспондирование позволяет оценить социальный порядок как правый и истинный во всех отношениях. Во-вторых, правовая философия далее не может не исследовать основания, которые легитимизируют само право. Вероятно, это принципиальная часть ее миссии.

Следует осмыслить одну достаточно заметную интригу. С одной стороны, философия права оценивает социальные процессы через линзу права и легального нормативного порядка. С другой стороны, она могла бы обдумать легитимность права. Это был бы серьезный метафизический шаг философской мысли. В этом случае она предпринимает усилия по осуществлению ${ }^{16}$ Кимлика У. Современная политическая философия: введение.
М.: Изд. Дом ГУ - ВШЭ, 2010. С. 22. 
DOI: $10.7256 / 1811-9018.2015 .3 .13279$

При цитировании этой статьи сноска на доі обязательна

\section{Право и политика $3(183) \cdot 2015$}

оснований возможности легитимности права в качестве важнейшей формы легитимности социального порядка.

В этом контексте хотелось бы предпринять попытку подчеркнуть синхронность дескриптивного и нормативного характера концепции легитимности права. В частности, легитимность как исходная точка социального порядка происходит из активности процедурных механизмов, включающих правила признания и принятия человеком и группами различных сторон социального бытия. Такие правила могут быть политическими, моральными и, несомненно, правовыми. Последние, а именно правовые, более надежны, чем другие для регулирования различных сфер общества. Эта констатация следует из того, что право содействует легитимности социального порядка, будучи компонентом последнего. В этой связи, сфера права должна быть рассмотрена как одна из подсистем легитимности, т.е. легитимности социального порядка. Это подразумевает возрастание веса рефлексии философии права над правовой легитимностью социального порядка, включающего моральный, религиозный, политический и правовой порядок.

Философия права исторически связана с теорией права, разрабатывающей главным образом вопросы нормативности и валидности права и законов. Для теории права вопрос отсылки к легитимности является дериватным. В чем заключается специфика позиции правовой философии? Это может быть понято в сравнении с подходом теории права. В частности, правовой нормативизм, будучи влиятельным трендом в теории права, принижает значимость проблемы легитимности. Теория права, представленная нормативизмом, как аргументированно подчеркивает Д. Прил, склоняется к редукции специфики легальных нюансов легитимности, принимая во внимание ее в качестве скорее политического, чем правового феномена ${ }^{17}$.

Эта позиция может быть объяснена интересом правового нормативизма к утверждению видения права именно как системы достоверных и реальных норм. Однако теория права в определенной степени не отвергает проблему легитимности. В философской перспективе легитимность, безусловно, опирается на нормативность. В свою очередь легальность как момент легитимности социального порядка и легитимность права в широком смысле не возможны без режима нормативности. Действительно, существование наложений и пересечений легитимности и нормативности является очевидным. Для теории права,

${ }^{17}$ Priel, D. The Significance of Legitimacy to Legal Theory. P. 10-18. Available at: http://www.law.ed.ac.uk/legaltheory/files/Priel_The\%Significance $\% 20$ of $\% 20$ Legitimacy $\% 20$ to $\% 20$ legal $\% 20$ theory.pdf. тем не менее, различение между первым и вторым является сомнительным. Харт, например, не концентрировался на этой проблеме, преимущественно уделяя внимание природе требований права и природе обязательств подчиняться законам. Различие между легитимностью и нормативностью имеет философскую почву. В моральной и политической философии, например, термин легитимность в отношении к власти часто трактуется как нормативный статус, предоставленный институтам управления с стороны граждан.

Философия права обладает богатым наследием в мыслительной сфере по концептуальному обоснованию легитимности и легитимации. Подчас мы можем видеть горячую дискуссию о природе этих феноменов. Бесспорно, что современная философия права вполне созрела для понимания двойственного характера рефлексии над отмеченными феноменами. С одной стороны, они подвергаются внимательному изучению через их анализ с точки зрения разных теоретических позиций. С другой стороны, философское изучение легитимности и легитимации было бы интересным как отдельная тема. Первый случай является важным для истории философии права. Второй является значимым для достижения понимания роли философии права в современном обществе. Это тот самый случай, дающий нам возможность увести философию права от подозрения в снижении ее реальной роли для обоснования новой - широкой - парадигмы легитимности.

При этом существует основание для акцентирования недостатка поддержания тесной связи между обоснованием легитимности философией права в историческом аспекте и современными усилиями по детализации легитимности. Прочные нити, несомненно, способствовали бы возрастанию ресурсов философии права. Однако современная философия права призвана решить новые проблемы легитимности, не появлявшиеся прежде. Они вызваны глобализацией права, сопровождаемой новым горизонтом правового регулирования, требующего новых подходов к оправданию права. Существенно, что философия права должна решить проблемы сущности и смысла права в исторически новой ситуации существования социума. Вот почему ей следует воспринимать новые тенденции на национальном, международном и наднациональном уровне, оформленные в тенденции эволюции права.

Тем не менее, новые условия приводят к изначальному философскому вопросу о том, почему существует легитимность. Этот феномен является коренным условием индивидуальной и социальной жизни. Он детерминирует структуру социального порядка, для которого легитим- 
DOI: $10.7256 / 1811-9018.2015 .3 .13279$

При цитировании этой статьи сноска на dоі обязательна

Правовая и политическая мысль

ность является атрибутивной. Легитимность может восприниматься в качестве признания и согласия с существующим социальным порядком, что прочно встроено в мотивы, цели и интересы реальных человеческих действий и деятельность. Таким образом, легитимность выступает как фундаментальная предпосылка легитимации как особого процесса, который выступает результатом формальных и неформальных процедур легитимации как специфического процесса подведения надлежащих основ (нормативных и смысловых) под существование тех или иных социально значимых феноменов, включая власть и право. Данные процедуры должны работать эффективно, иначе социальный порядок будет подвержен эрозии. Деформация социального порядка дезориентирует человеческое поведение и вызывает социальные конфликты и личностную депривацию.

Таким образом, целевые задачи философии права - энергичное обсуждение механизмов легитимности и экспликация их разрывов. Эти концептуальные действия имеют, соответственно, практический эффект. В этом случае разворачивается ее функция по обоснованию социальных норм и принципов, включая критическую позицию по отношению к ним. Вдобавок, философия права стремится не только к простому восстановлению существующих структур легитимности, но к выработке более адекватных концептуальных контуров последней. Отсюда вполне зримой становится сфера активности философии права. Очевидно, что легитимность многоаспектна. Для философии права важно концентрироваться главным образом на политическом и правовом аспектах легитимности и соответствующих процедурах. Тем не менее, моральный аспект легитимности социального порядка также должен быть принят во внимание в рамках концептуализации, осуществляемой философией права.

Рассмотрение философией права моральной, политической и правовой легитимации детализируется в конкретизации легитимирующей функции этой философии. Несмотря на то, что философия права работает в специальных сферах, она сохраняет максимальную высоту философской мысли. Философская мысль, проникнутая специальными философскими предпочтениями, является нормальным явлением, релевантным правовой философии. Результат этого факта представляет собой мозаику ее усилий по реконструкции социальной легитимности. Один из более значимых элементов такого плюрализма специфика создания связи между аспектами социальной легитимности. Также интересно, что различие в интенциях философских усилий заключается в конструировании и деконструкции дизайнов легитимности.
Авторитет философии права базируется на скорректированном балансе не только между различными аспектами легитимности и способами их упорядочения, но также между интенциями конструкции и деконструкции. Современная социальная философия должна быть внимательна к этому моменту в рамках своих попыток по созданию должного образа легитимности социального порядка. Дело в том, что этот образ в качестве условия плюрализма расширяет требования к новому подходу к содержанию, а также структуре легитимности социального порядка. Содержание и структура связаны с новизной в социальном порядке, потому что легитимность социального порядка находится по воздействием эволюции социальных институтов, отношений и норм, регулирующих их.

Современный социальный порядок не может быть интерпретирован в качестве абсолютно независимой реальности. Сдвиг в социальной организации поднимает вопросы относительно появления гетерономных тенденций в праве и морали. Эти тенденции, будучи связаны с постмодернистской реальностью, означают такой феномен как моральную и правовую персональную суверенность, возрастающую благодаря развитию цифровой среды. Это следует из того, что традиционные образы, например, естественного права, стали узкими для современной, а также постсовременной философии права и их теорий легитимности и легитимации. Однако философия естественного права продолжает сохранять определенную привлекательность, несмотря на факт дигитализации индивидуальной и общественной жизни. Современный человек, обладающий автономной и критической позицией, вопреки факту манипуляции сознанием, сохраняет критические позиции. В этой ситуации доктрина естественного права видится способной быть идеологической опорой должного права.

Легитимность права, выступающая ключевым моментом для легитимности власти, включает различные аспекты, такие как признание смысла и необходимости существования права. Это приводит к утверждению готовности подчиняться правовым правилам, в том числе исходящих от власти. Традиционно предпринимая в историческом плане усилия по обоснованию права, философия права тем самым содействовала его легитимности в только что указанном смысле. Эти усилия следует признать неотъемлемой частью механизма легитимации права на высшем уровне правового сознания. С предельной четкостью философия права применительно к каждой исторической эпохе стремиться найти и зафиксировать смысловую и ценностную основу права как правового бытия человека и общества. Одновременно 
DOI: $10.7256 / 1811-9018.2015 .3 .13279$

При цитировании этой статьи сноска на доі обязательна

\section{Право и политика $3(183) \cdot 2015$}

это определяет некий новый подход к праву - не просто как к нормативной системе, а как нормативной системе, которая легитимизирует многочисленные явления социокультурной жизни не только как правомерные и неправомерные, но как легитимные (правильные, истинные) и нелигитимные (неправильные, неистинные). Тем самым право оказывает поддержку важнейшей структуре, которая определяет развитие общества посредством подразделения последнего на реальность сущего и реальность должного. Данный подход суть обновление концепции ценности права, которая уточняет содержание его ценностного звучания.

Право в значительно степени представляет собой огромную часть социальных норм, которая обеспечивает стабильность социального порядка. Следует ли подвергать право самостоятельной оценке по упомянутым критериям правильности и неправильности? Необходимость этого могла бы быть аргументирована тем, что достижение прочной легитимности предполагает критическое рассмотрение состоятельности права. Это тезис проистекает из презумпции о том, что право - это основа для заключений о легитимности власти, но также о легитимности иных явлений и институтов. Право должно делать это объективно и беспристрастно, не формулируя окончательные суждения, но преимущественно указывая на возможность приобретениями теми или иными явлениями, утратившими легитимность или вступившими в зону кризиса своей легитимности, новых контуров их признания и доверия к ним. Это подразумевает, что мерило должно быть безукоризненным. Вряд ли право может давать основания для признания власти, государства и т.д. в качестве легитимных, если авторитет самого права не велик. В последнем случае формально-правовая легитимация будет зыбкой и неуверенной.

3. Содержательные контуры легитимности права в контексте широкого подхода к праву. Отличительная черта права - его способность к настройке собственной легитимности и отсутствие боязни критического само-рассмотрения, осуществляемого на уровне профессионального и массового правосознания. К тому же право имманентно обладает способностью к самоудвоению в форме разных плоскостей, одна из которых становится мерилом другой. Право включает в себя фундаментальные идеи, принципы, которые позволяют оценить так называемое действующее право. На наш взгляд, данный блок обладает исконной и неопровергаемой легитимностью, однако его историческое наполнение в позитивном праве предполагает эволюцию его смыслов.
Не вызывает сомнение, что главное обоснование права как легитимного права заключает в его совместимости с социальными ценностями, что тем не менее подразумевает очень сложную теоретическую тему. Пока же можно исходить из признания эвристики этого тезиса. В соответствии с подходом В. Садурски, предпринимающего критическое исследование «демократии без ценностей», формула «демократия-плюс», ставящая под сомнение теоретическую модель «демократии без ценностей», ценностный подход предполагает, что право для того, чтобы быть легитимным, должно быть воплощать определенные субстанциональные ценности ${ }^{18}$.

Группа авторов во главе с известным философом права Т. Тайлером разделяет и детализирует ценностный подход в отношении к законам и правилам. Ими утверждается, что правила и законы приобретают легитимный характер, когда они совместимы с моральными ценностями при одновременной совместимости личностных ценностей с правом. Отсюда ценности должны совпадать с правом. Господство же в обществе противоположных систем ценностей может подорвать право ${ }^{19}$. В некотором смысле, сказанное может быть распространено на легитимность права в целом. Ценностно ориентированный подход к обоснованию легитимности права проистекает из сосредоточения на природе и содержании ценностей, которые могут быть основой для оценки права и законов в отношении их легитимности или нелегитимности. Однако ценности не являются абсолютной точкой отсчета из-за их исторической и групповой изменчивости, тем более, что система ценностных предпочтений существенным образом усложняется в эпоху глобализации. В свете последнего обстоятельства ценностный релятивизм делает легитимность права очень проблематичной, как никогда ранее.

Акцентированный взгляд предоставляет возможность для детализации содержательных границ ценностного подхода к легитимности. С этой целью обратимся к широко распространенной концепции процедурной справедливости, затрагивающей справедливость и транспарентность процессов, посредством которых принимаются решения и совершаются действия. Примечательно, что концепция процедурной справедливости распространяется сегодня на

\footnotetext{
${ }^{18}$ Sadurski, W. Law's Legitimacy and 'Democracy-Plus' // Oxford Journal of Legal Studies, 2006. Vol. 26 (2). P. 379.

${ }^{19}$ Murphy, K., Tyler, T.R., Curtis, A. Nurturing Regulatory Compliance: Is Procedural Justice Effective When People Question the Legitimacy of Law? // Regulation \& Governance, 2006. Vol. 3(1). P. 3.
} 
DOI: $10.7256 / 1811-9018.2015 .3 .13279$

При цитировании этой статьи сноска на dоі обязательна

Правовая и политическая мысль

органы судебной власти ${ }^{20}$ и полиции ${ }^{21}$, что означает возникновение нового предметного поля для теории легитимности. Рассматриваемый подход - достаточно привлекательная схема, описывающая феномен легитимности именно как легитимность власти, так и, в принципе, легитимность права.

Процедурная справедливость имеет много аспектов и в конденсированной форме, будучи артикулирована Ролзом, стала солидным подходом к описанию тесно связанных между собой феноменов легитимности власти и легитимности права ${ }^{22}$. Однако, зачастую этот подход часто лишен некоторых важных моментов. Как отметил К. Марфи, теория процедурной справедливости акцентирована на том, как люди воспринимают легитимность властей, но в то же время игнорирует то, как люди могут воспринимать легитимность законов и правил. Действительно, теория процедурной справедливости затемняет то, почему и на какой основе процедуры, придающие легитимность власти, сами являются легитимными. Нет сомнения, что процедурная справедливость является релевантной для приведения поведения в соответствие с требованиями власти и делает возможной подчинение праву. В тоже время правовые процедуры должны иметь глубокое обоснование для того, чтобы быть почвой для принятия решений и совершения действий. С учетом высказанных соображений, ценностный подход предоставляет возможность пролить свет на достаточно неясную основу правильности легальных процедур, следование которым придает решениям и действия людей и властей правовой характер. Концепция процедурной справедливости придает особое внимание следованию формальным процедурам в аспекте формальных целей, но не ценностей, которые не подлежат полной формализации.

Если исходить исключительно из концепции процедурной справедливости ${ }^{23}$, то недостаточно понятно,

${ }^{20}$ Gribnau, J.L.M. Legitimacy of the Judiciary // Electronic Journal of Comparative Law, 2002. Vol. 6(4). P. 26 - 46.

${ }^{21}$ Kochel, T.R. Can Police Legitimacy Promote Collective Efficacy? // Justice Quarterly, 2011. Vol. 29(3). P. 384 - 419; Smith, D.J. New Challenges to Police Legitimacy, in Henry, A., Smith, D.J. (eds.) Transformations of Policing. Burlington: Ashgate, 2007. P. 273 - 306.

${ }^{22}$ May, L., Morrow, P. Procedural Justice. Burlington, 2012; Tyler, T.R. (ed.) Procedural Justice, Burlington, 2005; Röhl, K. F., Machura, S. Procedural Justice. Burlington, 1997.

${ }^{23}$ Smith, D.J. The Foundations of Legitimacy in Tyler, T.R. (ed.) Legitimacy and Criminal Justice: International Perspectives. New York: Russell Sage Foundation, 2007. P. 31 - 32; See also: Bottoms, A., Tankebe, J. Beyond Procedural Justice: A Dialogic Approach to Legitimacy in Criminal Justice // The Journal of Criminal Law \& Criminology, 2012. Vol. 102(1). P. 119 - 170; May, L., Morrow, P. Procedural Justice. Burlington: Ashgate, 2012; Tyler, T.R. (ed.) Procedural Justice, Burlington: Ashgate, 2005. Vol I, II; Röhl, K. F., Machura, S. Procedural являются ли требования власти «говорящим законом» или средством для правления права. Такая модель легитимности, как процедурная справедливость хороша для объяснения поведенческих аспектов социального порядка, но не для широко видения его легитимности и легитимности права, понятого не как совокупность легальных правил, а как правовой универсум человеческого бытия. Именно в рамках последней позиции, граждане как субъекты права могут вопрошать относительно легитимности материальных и процедурных правил, находящихся в основе легитимности власти. В том случае, если законы и право нелегитимны, то это автоматически ведет к нелегитимности действий и решений ветвей власти.

Когда мы говорим о легитимности права мы должны отдавать отчет о предмете данной теоретической конструкции. Понятие легитимности приложимо к тому, что называют действующим, или позитивным правом, а также вполне приложимо к тому, что именуется правовым порядком, являющимся результатом правового воздействия. Аналогично легитимации права, правовой порядок (правовой порядок общества) также должен подвергаться легитимации. Благодаря этому становится возможной легитимность социального порядка в целом. Легитимность правового порядка, являющейся одним из сюжетов историко-философской мысли ${ }^{24}$, является весьма существенной для нормального и устойчивого функционирования гражданского общества и государства, а также их институтов. Поэтому в общем плане легитимность является духовной и прагматической ценностью.

Трудно и даже невозможно настаивать на несправедливости и несвободе как фундаментальных основах социального порядка. Несмотря на то что, идеи свободы, справедливости и равенства всегда следует гармонизировать по причине существующей напряженности между ними, они задают предельный горизонт индивидуального и общественного существования, воплощавшегося и воплощающегося в разной степени в правовом порядке общества как существенном измерения последних. Описываемый априорный блок, составляющий естественное право, осуществлял и продолжает осуществлять настройку позитивного права. Разумеется, что возникающие паузы в такой настройке сопровождаются кризисами легитимности права и наряду с этим - кризисами правовой легитимности тех

Justice. Burlington: Ashgate, 1997; May, L., Morrow, P. Procedural Justice. Burlington, 2012.

${ }^{24}$ Conkin, W.E. Hegel's Laws: The Legitimacy of a Modern Legal Order. Stanford, 2008. 
DOI: $10.7256 / 1811-9018.2015 .3 .13279$

При цитировании этой статьи сноска на доі обязательна

\section{Право и политика $3(183) \cdot 2015$}

или иных общественных явлений, а, в конечном счете, и кризисами всей машинерии легитимности.

Итак, наличие указанного априорного (и даже трансцендентального ядра в духе неокантианской философии права) - условие легитимности права. Но данное ядро в свою очередь должно подлежать оправданию, защите, модернизации. Все это открывает новые предметные поля для философии права, призванной к осмыслению необходимых сдвигов в содержательной ткани права и его легитимации. Более того, философия права - центральный пункт легитимации права, понятой как его теоретическое и мировоззренческое обоснование. Эти усилия существенно расширяют функции философии права в современном мире. Таким образом, философия права не просто изучает легитимацию и делегитимацию общественных явлений в аспекте легитимации и делегитимации права, но выполняет функцию по укреплению легитимности права, указывая не только обосновывающий его блок принципов, идей и ценностей, но и предлагает меры по совершенствованию последнего, по лучшей имплементации его в позитивное право, тем самым содействуя легитимации права в общественном сознании.

Действительно, право вряд ли будет справляться со своими задачами, если оно не будет авторитетным. Отсюда следует вопрос о системной оценке действующего права, в которую входят не только критерии его эффективности и целесообразности, но и критерии мировоззренческой обоснованности и способности соответствовать велениям времени. Более практичный аналог легитимности права - приемлемость населением. Поскольку право рассчитано на всех, то о его приемлемости можно говорить только в случае баланса интересов разных групп интересов. Это означает, что легитимность действующего права есть следствие общественного консенсуса. С другой стороны, само действующее право посредством учета групп интересов может повысить уровень своей легитимности.

Существует обоснованная позиция, которая предусматривает различие между правом и законами ${ }^{25}$. Система законов, а также их исполнение, не являются самодостаточными. Законодательство и юридическая практика, другие правовые формы интегрируются согласно неуловимой системе норм, принципов и ценностей, именуемых естественным правом. Как подчеркнуто выше, естественно-правовая риторика является сегодня достаточно условной, ибо центр че-

${ }^{25}$ Нерсесян В.С. Право и правовой закон: становление и развитие. Под. ред. В.В. Лапаевой. М.: Норма, 2009. ловеческой жизни смещен в технологическую среду. Но естественно-правовой подход сохраняет возможности дальнейшего развития, с чем связано придание праву, понятому уже как система прагматических правил, глубинного обоснования. Другими словами, в соответствии с естественно-правовой парадигмой право подчинено великим гуманистическим идеям. Это касается правотворчества, исполнения права, подчинения праву и свободной реализации правовых норм гражданами. Сохраняя позитивные моменты естественно-правовой традиции, необходимо принять достаточно абстрактную позицию последнего.

Что представляет собой измерение права в широком смысле? Является ли оно реальностью или презумпцией? Я считаю это измерение, задающее легитимность формальным законам, презумпцией, а более конкретно - идеологической системой. Однако эта презумпция более или менее валидна, так как духовные интенции являются составной частью правового сознания. Кризис легитимности права начался с принижения потребности сохранения, поддержания и развития духовноправовых интенций. Помимо этого, вполне возможно говорить об ослаблении и даже потере этих интенций, определенных как презумпция.

Таким образом, универсум права, санкционирующий правовой порядок общества, будучи презумпцией, может быть также оценен как «вера в рациональность права». Эта формулировка принадлежит М. Веберу. Он полагал, что всеобщая вера в рациональность права является основанием признания политической власти в качестве рациональной в том случае, когда последняя действует согласно установленным правовым процедур. Граждане действуют в соответствии с такой верой и уверены в рациональности права, что ведет их к уверенности в подлинности содержания и применения права и принятию ими обязанности подчиняться. В этом случае мы видим триумф правовой легитимности социального порядка. Согласно позиции автора данной статьи, было бы верным утверждать, что вера в рациональность права должна охватывать граждан и все ветви власти, т.е. должна быть всеобщей.

Далеко не случайно, что согласно подходу М. Вебера правовая рациональность стала одной из доминантных форм среди форм других легитимности. Как я думаю, Вебер уделял чрезмерное внимание легальности власти как источнику ее легитимности. Этот факт может быть обоснован центральным значением легальной власти для правового характера социального порядка и для правовой легитимности социального порядка. Легальная власть продуцирует законы и решения, основанные на 
законах. От властей, создающих законы и обеспечивающих их исполнение, требуется быть легальными и обладать легитимностью. По моему мнению, правовая легальность власти не сводится к рациональности возвышенного универсума права. В ситуации конституционного государства граждане должны главным образом подчиняться праву и распоряжениям власти, которые не имеют независимой значимости, ибо они олицетворяют, в принципе, власть права. Власть права сопровождается интенциями приверженности праву. Эти интенции сродни с верой в право и верой в его рациональность.

Следовательно, легитимность включает некоторые моменты верований и убеждений в качестве духовной основы, оформляющей право и правовую культуру. Правовые верования и убеждения составляют фундаментальный базис легитимности социального порядка. В частности, что касается ситуации политической легитимности в демократическом обществе, граждане верят и убеждены при этом, что правительственные действия соответствуют конституционному мандату. Как следствие, существуют убеждения в том, что юридические правила и судебные решения являются правильными и истинными. Легальность властей, будучи помещенной в контекст доверия к ним, ведет к признанию легитимности социального порядка. В традиционных обществах основа верований и убеждений в легальность власти покоилась на небесных знамениях и нечто в этом роде. Во всяком случае, верования и убеждения в отношении легальности власти являлись дополнением к верованиям и убеждениям в правильности, истинности и справедливости права, его рациональности или божественности.

Кризис данного типа легитимности в период секуляризации сознания и общественных отношений начался с кризиса ментальных оснований и нашел свое продолжение в процедурном кризисе. В целом, история сопровождалась различными кризисами легитимности. Поэтому текущий кризис - одна из форм в серии смены парадигм легитимности, включая легитимность права. В целом генеральная линия заключается в тенденции к рационализации основ легитимности социального порядка, права и власти и, соответственно, в рациональном философском обосновании легитимности. Это требует учета динамики смены парадигм рациональности в философии и обществе. Однако эти обстоятельства не уменьшают роль верований и убеждений, существующих на уровне идеологии и ментальности в рамках правового сознания. Их рационализация является ограниченной. Поэтому надо учитывать, что полная рационализация легитимности является хрупкой по своей природе, так как правовое сознание утрачивает элементы абсолютных скреп, представленных в форме правовых верований и убеждений. Ввиду этого экстремальный релятивизм как релятивизация рациональности права и правовой жизни сопряжены с тенденциями перманентного кризиса легитимности.

В этом свете концепция Вебера, построенная на принципе человеческой свободы и рациональности и дающая рост целому ряду институтов легитимации, нуждается в уточнении. Перспективы современной демократии побуждают поиск новой формы демократической легитимности, опирающейся на рассмотрении людей в качестве акторов политических и правовых процессов. Это не означает, что необходимо отвергать идею рациональности, напротив, следует обсуждать ее новую парадигму. Однако в современной правовой ментальности преобладает настоятельное требование справедливости, а не рациональности. Вместе с тем, современная справедливость должна быть рациональной: рациональность следует интерпретировать не как обертку легитимности, а как подкрепление справедливости. Баланс между рациональностью и справедливость требует обновления правовых верований и убеждений людей.

По крайней мере, для К. Шмидта вера в рациональность правовой практики как основа легитимности была проблематичной. В противоположность Веберу он утверждал, что легитимность норм основывается на аккламации их со стороны людей ${ }^{26}$. Не соглашаясь с концепцией Вебера о вере в рациональность права как главного источника легитимности, Шмидт указывал на всеобщий упадок современной рациональности как изначального источника легитимности Пытаясь показать источник кризиса парламентской демократии, он подчеркивал, что такой кризис был вызван преобладанием веры в волю над верой в разум ${ }^{27}$.

Однако всеобщий кризис рациональности, существующей в качестве фундамента легитимности, не означает провала рациональности. Вера в волю, соотнесенная с ситуацией кризиса политической и правовой легитимности, представляет опасность для социальных институтов. Кроме того, вера в волю едва ли может быть фундаментом права, основанного на идее справедливости, сбалансированной, в принципе, с рациональностью. Отсюда политическая легитимность не должна искаться вне авторитета и рациональности права. В свою очередь легитимность права не должна

\footnotetext{
${ }^{26}$ Schmitt, C. Legality and Legitimacy. Durham, London, 2004, P. XV.

${ }^{27}$ Schmitt, C. The Crisis of Parliamentary Democracy. Cambridge, London, 1988, P. $48-50$.
} 
DOI: $10.7256 / 1811-9018.2015 .3 .13279$

При цитировании этой статьи сноска на доі обязательна

\section{Право и политика $3(183) \cdot 2015$}

усматриваться вне принципов правильности, справедливости и, конечно, рациональности.

Достаточно обоснованным является подход к политической легитимности, который был выработан Роулсом, следовавшего кантовскому представлению о различии между легитимностью и эффективностью власти, а также допускавшего случай, когда обязательство подчиняться не прекращается в случае, если законы не справедливы. Ролс утверждал, что политическая власть является легитимной только тогда, когда она осуществляется в соответствии с писанной или не писанной конституцией, разумное основание которой одобряют все граждане в соответствии с их коллективным разумом ${ }^{28}$. В той мере, в какой ролсовская концепция политической легитимности связана со справедливостью и общей человеческой аргументацией, представления философии права о легитимности права также вполне могут подразумевать такие общие ориентации, как правильность, честность и справедливость в качестве опоры его легитимности.

Думается, что брешь в упомянутых верованиях или, в моей формулировке, в презумпции «возвышенного универсума права» коррелирует кризису легитимации и кризису привычных механизмов легитимации. Современное человечество теряет доверие к гомогенности и автономности мира правовых идей и ценностей, а также к всеобщим социо-культурным идеям. Это может быть диагностировано как сужение ментальности, включая правовой менталитет. Все это следует отметить в качестве симптомов моральной и духовной деградации. Современное человечество теряет доверие не только к правовым принципам, но и к мудрости законодателей. Расчет законодателей ныне не является достаточным основанием для легитимности права. Как бы то ни было, этот кризис может быть рассмотрен как изменение модели права и легитимности права, а именно как переход к релятивному, плюралистическому и гетерономному миру правовых оснований, существующих в качестве презумпций. Полное обновление правовых оснований является делом будущего. Это определяется настоятельной потребностью выхода за пределы дезориентированного с точки зрения права поведения.

Вместе с тем, кризисные процессы в праве и правосознании, несмотря на их расширение, ограничиваются некоторыми феноменами. Так, современное право располагает одной существенной деталью, а именно правами человека. Конституционный принцип правления закона коррелирует абсолютным ценностям прав чело- века, которые коренятся в презумпции человеческого достоинства, подразумевающего личную свободу и значение. Современное право включает последнее как компонент, который служит лучшим примером тотально не рационализированных верований и убеждений. Так, права человека, происходящие из презумпции человеческого достоинства, являются тем, что наиболее дорого людям. Право, регулирующее и защищающее их, является главным образом правом права человек.

Права человека стали мощным фактором правовой легитимности социального порядка и основой легитимности правового порядка, в тоже время, будучи слабым звеном. Этот факт может быть объяснен не только уязвимостью их защиты и осуществления, но и трудностью реализации заложенной в их основе идеи равноправия. В свою очередь это требует новых подходов к пониманию принципа равенства в праве. В этом смысле важная роль принадлежит исследованию В. Санадрски ${ }^{29}$. Он исследует сферу юридического равенства и аргументирует некоторые особые критерии дифференциации и аргументирует, что приемлемая концепция недискриминации может быть сконструирована через рефлексивный равновесный процесс и что следует отрицать необдуманное предположение о том, что наличие некоторого особого критерия дифференциации необходимо скрывает юридическую классификацию в качестве дискриминации. Из этого можно вывести мысль о том, что правовое закрепление дифференциации, в том случае, если оно соответствуют принципам права и общественным ценностям, является составной частью признания права как легитимного явления.

Bсе рассмотренные выводы указывают, что существует потребность детализировать отношения между легальностью, легитимностью и легитимностью права. Действительно, легальность, включая легальность власти, - значительный элемент легитимности права, в частности, и легитимности социального порядка в целом. Легальность относится к действиям людей, а также к действиям и решениям исполнительной власти, судебной власти и законодательству. Основание их легальности - это корреспондирование законам. При этом, те же законы должны корреспондировать праву в его широком понимании. Вследствие легальных оснований власть становится политической властью, а благодаря легитимности становится аттрактором легитимного социального порядка, корреспондирующего легитимному праву. Для интеграции в легитимность права и в легитимность социального порядка власть должна 
корреспондировать универсуму права. Такое корреспондирование есть существенная часть социальной легитимности. Поэтому легальность власти есть только лишь процедурный инструмент легитимности социального порядка. Действия, включая действия власти, могут обладать критерием легальности, но этого недостаточно для признания существования легитимности. Общество заостренно относится к возможному напряжению между легальностью и легитимностью. Кризис легальности подтачивает правовой порядок общества и, как следствие, легитимность в целом. В этих условиях появляется потребность обновления правового универсума для того, чтобы сохранить приверженность ему.

Одновременно, легитимность права не только одна из форм легитимности, но такая форма, которая воздействует на валидную реализацию человеческих целей и интенций. Что из себя представляет базис правовой легитимности социального порядка? Это моральные и даже религиозные интенции, пересекающиеся с фундаментальными правовыми интенциями и устанавливающими единый морально-правовой комплекс. Данный тезис может быть продемонстрирован на примере идеи, ценности и принципе справедливости. Поэтому универсум права сопротивляется окончательной рационализации. Это подтверждает предложение о презюмируемом характере возвышенного универсума права, санкционирующего легитимность социального порядка. В целом, правовой универсум имеет морально-правовой характер, что вполне может совпадать с выводами теории естественного права.

Правовая жизнь в ее различных формах, таких как исполнительная и законодательная деятельность, охватывая реализацию прав человека, должна постоянно иметь в виду этот морально-правовой универсум. Забвение базисных обоснований правового порядка общества ведет к кризису легитимности. Возможности не заключаются в простом претерпевании негативных процессов социального беспорядка. Преодоление кризиса предполагает интенсифицированный поиск релевантных моделей механизмов легитимации. Кризис легитимности власти, права и социального порядка должен быть не приостановлен, а должен быть разрешен благодаря содействию со стороны потенциалу философии права. Философия права должна разрабатывать концептуальную структуру создания новой правовой легитимности социального порядка на основе нового и усовершенствованного механизма легитимации права. Вполне понятно, что одной только теоретической работы недостаточно для того, чтобы право было легитимным на практике.
Вместе с тем философско-правовая легитимация являет собой аспект предельно широко понятых процессов легитимации права и выступает в качестве их теоретическо-мировоззренческой формы. Теоретическая легитимация права и связанные с ней направления по его практической легитимации предполагают изначальный плюрализм философско-правовой мысли. Однако в этом плюрализме скрываются опасности фрагментации, когда в соответствии с разными типами правопонимания возникаю самостоятельные модели легитимации права. Поэтому условием действенного легитимирующего воздействия на право со стороны философии может выступить конструктивный диалог и некоторый консенсус по определенным вопросам видения того, что есть право.

Не менее важным аспектом выступает диалог и консенсус по поводу того, что есть легитимность права и в чем заключается кризис его легитимности. Ясно, что уловить все аспекты кризиса легитимности, включая все аспекты кризиса легитимности права, достаточно трудно. Но формирование достаточно системного образа данного кризиса вполне возможно в случае содержательного и структурного усложнения философии права. Это могло бы рассмотрено как возрастание ее потенциала в направлении концептуального разрешения проблемы легитимности, с которыми столкнулось современное человечество. Поэтому философия права стоит перед задачей создания концептуального равновесия, во-первых, между рациональностью и верованиями, во-вторых, между справедливостью и равенством, а также, в-третьих, между свободой и равенством на уровне структуры легитимности.

В завершение необходимо отметить одну из наиболее значимых тенденций развития философии права, а именно анализ легитимности системы международных отношений и международно-правовых оснований, поддерживающих их ${ }^{30}$. В частности, национальное право интегрировано в международно-правовой порядок и далее - в глобальное право. В результате появляется новое видение того, что есть право и, соответственно, что есть легитимность. Помимо этого, в ходе дискуссий о справедливости, свободе и равенстве в рамках международных отношений, урегулированных международным правом, поднимается вопрос о понятии «философия права». Это

\footnotetext{
${ }^{30}$ Buchanan, A., Keohane, R.O. The Legitimacy of Global Governance Institutions // Ethics and International Affairs, 2006. Vol. 20(4). P. 405 -437; Byrd, B. S., Hruschka, J. From the State of Nature to the Juridical State of States // Law and Philosophy, 2008. Vol. 27. P. $599-641$.
} 
DOI: $10.7256 / 1811-9018.2015 .3 .13279$

При цитировании этой статьи сноска на doi обязательна

\section{Право и политика 3 (183) 2015}

обращает нас к проблемам легитимности в международном праве и международно-правовой системе как самостоятельных предметов изучения ${ }^{31}$. Во многом, это обусловлено тем, что национальное право может быть признано как легитимное, если оно совместимо с международно-правовыми стандартами. В результате, привычное обоснование легитимности права, понимаемой как легитимность именно национального права решительным образом перемещается к новой предметной сфере, демонстрирующей потребность в обосновании легитимности глобальных правовых стандартов в качестве меры легитимности национального права. К тому же, глобальные процессы, проблематизирующие государственный суверенитет, могут подорвать суверенитет национальных правовых систем, в то время как легитимность национального права продолжает мыслиться в качестве легитимности суверенного права. Все это имеет большое значение для дальнейшей работы философско-правовой мысли и заслуживает тщательного исследования.

\section{Библиография:}

1. Гаджиев Г.А. Онтология права: (критическое исследование юридического концепта действительности). М.: Норма, 2014. (320 с.).

2. Дзоло Д. Демократия и сложность: реалистический подход. М.: Изд. Дом ГУ - ВШЭ, 2010. С. 311 - 312 . (320 с.).

3. Кимлика У. Современная политическая философия: введение. М.: Изд. Дом ГУ - ВШЭ, 2010. (592 с.).

4. Круч К. Пост-демократия. М.: Изд. Дом ГУ - ВШЭ, 2010. (192 с.). Льюкс С. Власть: Радикальный взгляд. М.: Изд. Дом ГУ - ВШЭ, 2010. (240 с.).

5. Малахов В.С. Государство в условиях глобализации. М.: Издательство «КДУ», 2007. (256 с.).

6. Нерсесян В.С. Право и правовой закон: становление и развитие. Под. ред. В.В. Лапаевой. М.: Норма, 2009. (384 с.).

7. Пермяков Ю.Е. Метаморфозы легитимности // Мир человека6 нормативное измерение - 3. Рациональность и легитимность. Сборник трудов международной научной конференции (Саратов, 13 - 15 июня 2013 г.). под ред. проф. И.Д. Невважая. Саратов: Издательство «Кубик», С. $307-314$.

8. Подорога В. Апология политического. М.: Изд. Дом ГУ - ВШЭ, 2010. (288 с.)

9. Шатило В.А. Вопросы легализации и легитимации государственной власти // Мир человека: нормативное измерение-3. Рациональность и легитимность. Сборник трудов международной научной конференции (Саратов, 13 - 15 июня 2013 г.). под ред. проф. И.Д. Невважая. Саратов: Издательство «Кубик», С. 348 - 349.

10. Шугуров М.В. Правовая субъектность и инверсии современной культуры // Общественные науки и современность. 2005. № 1. C. 79 - 94.

11. Besson, S., Tasioulas, J. (eds.) The Philosophy of International Law. Oxford: Oxford University Press, 2010. (626 pp.).

12. Bottoms, A., Tankebe, J. Beyond Procedural Justice: A Dialogic Approach to Legitimacy in Criminal Justice // The Journal of Criminal Law \& Criminology, 2012. Vol. 102(1). P. $119-170$.

13. Brook T. The Legitimacy of Law in Literature: the Case of Albion W. Tourgée // Elon Law Review, 2012. Vol. 5(1). P. 170 - 198.

14. Buchanan, A., Keohane, R. O. The Legitimacy of Global Governance Institutions // Ethics and International Affairs, 2006. Vol. 20(4). P. $405-437$.

15. Buchanan, A. Political Legitimacy and Democracy // Ethics, 2002. Vol. 112(4). P. 689 - 719.

16. Byrd, B. S., Hruschka, J. From the State of Nature to the Juridical State of States // Law and Philosophy, 2008. Vol. 27(6). P. 599-641.

17. Cohen, J.L. Globalization and Sovereignty. Rethinking Legality, Legitimacy, and Constitutionalism. Cambridge: Cambridge University Press, 2012. (442 pp.).

18. Conkin, W.E. Hegel's Laws: The Legitimacy of a Modern Legal Order. Stanford: Stanford University Press, 2008. (381 pp.).

19. Dyzenhaus, D. Hobbes and the Legitimacy of Law // Law and Philosophy, 2001. Vol. 2(5). P. $461-498$.

20. Edmundson, W.A. (ed.) The Duty to Obey the Law Selected Philosophical Readings. Oxford: Rowman\&Littlefield, 1999 . (352 pp.).

21. Estlund, D. M. Democratic Authority: A Philosophical Framework. Princeton: Princeton University Press, 2008. (312 pp.).

22. Jackson, J., Bradford, B., Hough, M., Mihil, A., Quinton, P., Tyler, T. Why Do People Comply with the Law? Legitimacy and the Influence of Legal Institutions // British Journal of Criminology, 2012. Vol. 52(6). P. 1051 - 1071.

23. Kochel, T.R. Can Police Legitimacy Promote Collective Efficacy? // Justice Quarterl y, 2011. Vol. 29(3). P. 384 - 419.

24. Lukas, H. M. (ed.) Legitimacy, Justice and Public International Law. Cambridge: Cambridge University Law? 2009. (333 pp.).

25. May, L., Morrow, P. Procedural Justice. Burlington: Ashgate, 2012. (513 pp.).

26. Murphy, K., Tyler, T.R., Curtis, A. Nurturing Regulatory Compliance: Is Procedural Justice Effective When People Question the Legitimacy of Law? // Regulation \& Governance, 2009. Vol. 3(1). P. 1 -26.

27. Rawls, J. Justice as Fairness: A Restatement. Cambridge: Harvard University Press, 2001. (214 pp.).

${ }^{31}$ Thomas, C.A. The Conception of Legitimacy and International Law. LSE Law, Social and Economy Working Papers 12/2013, 2013. Available at: http://www.lse.ac.uk/collections/wps/WPS2013-12.Thomas. pdf; Besson, S., Tasioulas, J. (eds.) The Philosophy of International Law. Oxford, 2010; Lukas, H. M. (ed.) Legitimacy, Justice and Public International Law. Cambridge, 2009. 
28. Röhl, K. F., Machura, S. Procedural Justice. Burlington: Ashgate, 1997. (240 pp.).

29. Sadurski, W. Equality and Legitimacy. Oxford: Oxford University Press, 2008. (250 pp.).

30. Sadurski, W. Law's Legitimacy and 'Democracy-Plus' // Oxford Journal of Legal Studies, 2006. Vol. $26(2)$. P. 377 - 409.

31. Schmitt, C. Legality and Legitimacy. Durham, London: Duke University Press Books, 2004. (216 pp.).

32. Schmitt, C. The Crisis of Parliamentary Democracy. Cambridge, London: The MIT Press, 1998. (184 pp.).

33. Simmons, A. Justification and Legitimacy: Essays on Rights and Obligations. Cambridge: Cambridge University Press, 2001. (276 pp.).

34. Smith, D.J. New Challenges to Police Legitimacy, in Henry, A., Smith, D.J. (eds.) Transformations of Policing. Burlington: Ashgate, 2007. P. 273 - 306.

35. Tyler, T.R. Why People Obey the Law. Princenton: Princenton University Press, 2006. (320 pp.).

36. Vinx, L. Hans Kelsen's Pure Theory of Law: Legality and Legitimacy. Oxford: Oxford University Press, 2007. (230 pp.).

37. Wellman, Ch., Simmons, J. Is There a Duty to Obey the Law? Cambridge: Cambridge University Press, 2005. (200 p.).

38. Wheatly, S. The Democratic Legitimacy of International Law. Portland: Hart Publishing, 2010. (400 pp.).

\section{References (transliterated):}

1. Gadzhiev G.A. Ontologiya prava: (kriticheskoe issledovanie yuridicheskogo kontsepta deistvitel'nosti). M.: Norma, 2014. (320 s.).

2. Dzolo D. Demokratiya i slozhnost': realisticheskii podkhod. M.: Izd. Dom GU - VShE, 2010. S. 311 - 312 . (320 s.).

3. Kimlika U. Sovremennaya politicheskaya filosofiya: vvedenie. M.: Izd. Dom GU - VShE, 2010. (592 s.).

4. Kruch K. Post-demokratiya. M.: Izd. Dom GU - VShE, 2010. (192 s.). L'yuks S. Vlast': Radikal'nyi vzglyad. M.: Izd. Dom GU - VShE, 2010. (240 s.).

5. Malakhov V.S. Gosudarstvo v usloviyakh globalizatsii. M.: Izdatel'stvo «KDU», 2007. (256 s.).

6. Nersesyan V.S. Pravo i pravovoi zakon: stanovlenie i razvitie. Pod. red. V.V. Lapaevoi. M.: Norma, 2009. (384 s.).

7. Permyakov Yu.E. Metamorfozy legitimnosti // Mir cheloveka6 normativnoe izmerenie - 3. Ratsional'nost' i legitimnost'. Sbornik trudov mezhdunarodnoi nauchnoi konferentsii (Saratov, 13 - 15 iyunya 2013 g.). pod red. prof. I.D. Nevvazhaya. Saratov: Izdatel'stvo «Kubik», S. $307-314$.

8. Podoroga V. Apologiya politicheskogo. M.: Izd. Dom GU - VShE, 2010. (288 s.)

9. Shatilo V.A. Voprosy legalizatsii i legitimatsii gosudarstvennoi vlasti // Mir cheloveka: normativnoe izmerenie - 3. Ratsional'nost' i legitimnost'. Sbornik trudov mezhdunarodnoi nauchnoi konferentsii (Saratov, 13 - 15 iyunya 2013 g.). pod red. prof. I.D. Nevvazhaya. Saratov: Izdatel'stvo «Kubik», S. 348 - 349.

10. Shugurov M.V. Pravovaya sub’ektnost’ i inversii sovremennoi kul’tury // Obshchestvennye nauki i sovremennost’. 2005. S. $79-94$.

11. Besson, S., Tasioulas, J. (eds.) The Philosophy of International Law. Oxford: Oxford University Press, 2010. (626 pp.).

12. Bottoms, A., Tankebe, J. Beyond Procedural Justice: A Dialogic Approach to Legitimacy in Criminal Justice // The Journal of Criminal Law \& Criminology, 2012. Vol. 102(1). R. 119 - 170.

13. Brook T. The Legitimacy of Law in Literature: the Case of Albion W. Tourgée // Elon Law Review, 2012. Vol. 5(1). R. 170 - 198.

14. Buchanan, A., Keohane, R. O. The Legitimacy of Global Governance Institutions // Ethics and International Affairs, 2006. Vol. 20(4). R. $405-437$.

15. Buchanan, A. Political Legitimacy and Democracy // Ethics, 2002. Vol. 112(4). R. 689 - 719.

16. Byrd, B. S., Hruschka, J. From the State of Nature to the Juridical State of States // Law and Philosophy, 2008. Vol. 27(6). R. $599-641$.

17. Cohen, J.L. Globalization and Sovereignty. Rethinking Legality, Legitimacy, and Constitutionalism. Cambridge: Cambridge University Press, 2012. (442 pp.).

18. Conkin, W.E. Hegel's Laws: The Legitimacy of a Modern Legal Order. Stanford: Stanford University Press, 2008. (381 pp.).

19. Dyzenhaus, D. Hobbes and the Legitimacy of Law // Law and Philosophy, 2001. Vol. 2(5). R. $461-498$.

20. Edmundson, W.A. (ed.) The Duty to Obey the Law Selected Philosophical Readings. Oxford: Rowman\&Littlefield, 1999. (352 pp.).

21. Estlund, D. M. Democratic Authority: A Philosophical Framework. Princeton: Princeton University Press, 2008. (312 pp.).

22. Jackson, J., Bradford, B., Hough, M., Mihil, A., Quinton, P., Tyler, T. Why Do People Comply with the Law? Legitimacy and the Influence of Legal Institutions // British Journal of Criminology, 2012. Vol. 52(6). R. 1051 - 1071.

23. Kochel, T.R. Can Police Legitimacy Promote Collective Efficacy? // Justice Quarterl y, 2011. Vol. $29(3)$. P. 384 - 419.

24. Lukas, H. M. (ed.) Legitimacy, Justice and Public International Law. Cambridge: Cambridge University Law? 2009. (333 pp.).

25. May, L., Morrow, P. Procedural Justice. Burlington: Ashgate, 2012. (513 pp.).

26. Murphy, K., Tyler, T.R., Curtis, A. Nurturing Regulatory Compliance: Is Procedural Justice Effective When People Question the Legitimacy of Law? // Regulation \& Governance, 2009. Vol. 3(1). R. 1 -26.

27. Rawls, J. Justice as Fairness: A Restatement. Cambridge: Harvard University Press, 2001. (214 pp.).

28. Röhl, K. F., Machura, S. Procedural Justice. Burlington: Ashgate, 1997. (240 pp.).

29. Sadurski, W. Equality and Legitimacy. Oxford: Oxford University Press, 2008. (250 pp.).

30. Sadurski, W. Law's Legitimacy and 'Democracy-Plus' // Oxford Journal of Legal Studies, 2006. Vol. 26(2). R. 377 - 409.

31. Schmitt, C. Legality and Legitimacy. Durham, London: Duke University Press Books, 2004. (216 pp.). 
DOI: $10.7256 / 1811-9018.2015 .3 .13279$

При цитировании этой статьи сноска на доі обязательна

\section{Право и политика $3(183) \cdot 2015$}

32. Schmitt, C. The Crisis of Parliamentary Democracy. Cambridge, London: The MIT Press, 1998. (184 pp.).

33. Simmons, A. Justification and Legitimacy: Essays on Rights and Obligations. Cambridge: Cambridge University Press, 2001. (276 pp.).

34. Smith, D.J. New Challenges to Police Legitimacy, in Henry, A., Smith, D.J. (eds.) Transformations of Policing. Burlington: Ashgate, 2007. R. $273-306$.

35. Tyler, T.R. Why People Obey the Law. Princenton: Princenton University Press, 2006. (320 pp.).

36. Vinx, L. Hans Kelsen's Pure Theory of Law: Legality and Legitimacy. Oxford: Oxford University Press, 2007. (230 pp.).

37. Wellman, Ch., Simmons, J. Is There a Duty to Obey the Law? Cambridge: Cambridge University Press, 2005. (200 p.).

38. Wheatly, S. The Democratic Legitimacy of International Law. Portland: Hart Publishing, 2010. (400 pp.). 